\title{
Article \\ Simulating and Comparing Different Vertical Greenery Systems Grouped into Categories Using EnergyPlus
}

\author{
Alberto Arenghi ${ }^{1, *(\mathbb{D}}$, Camilla Perra ${ }^{2}{ }^{-1}$ and Marco Caffi ${ }^{1,3}$ \\ 1 Department of Civil, Architectural, Environmental Engineering and Mathematics (DICATAM), \\ University of Brescia, 25123 Brescia, Italy; marco.caffi@unibs.it \\ 2 Free Lance Architectural Engineer in Brescia, 25128 Brescia, Italy; camilla.perra1223@gmail.com \\ 3 Green Building Council Italia, 38068 Rovereto, Italy \\ * Correspondence: alberto.arenghi@unibs.it; Tel.: +39-030-3711231
}

\section{check for}

updates

Citation: Arenghi, A.; Perra, C.; Caffi, M. Simulating and Comparing Different Vertical Greenery Systems Grouped into Categories Using EnergyPlus. Appl. Sci. 2021, 11, 4802. https: / / doi.org/10.3390/ app11114802

Academic Editors: Tiziana Poli, Luisa F. Cabeza, Andrea Giovanni Mainini, Gabriele Lobaccaro, Juan Diego Blanco Cadena and Mitja Košir

Received: 7 April 2021

Accepted: 20 May 2021

Published: 24 May 2021

Publisher's Note: MDPI stays neutral with regard to jurisdictional claims in published maps and institutional affiliations.

Copyright: (c) 2021 by the authors. Licensee MDPI, Basel, Switzerland. This article is an open access article distributed under the terms and conditions of the Creative Commons Attribution (CC BY) license (https:/ / creativecommons.org/licenses/by/ $4.0 /)$.

\begin{abstract}
The use of vegetation for the energy efficiency of buildings is an increasingly widespread practice; therefore, the possibility of representing these systems correctly with the use of simulation software is essential. VGS performances have been widely studied, but currently, the lack of a unique simulation method to assess the efficiency of different types of VGS and the absence of studies evaluating the performances of all the systems available, proposing simulation models for each of them, leads to an incomplete energy representation. The aim of this study is to achieve a consistent and complete simulation method, comparing the different systems' performances. The research is made up of five main steps. Firstly, a classification to group these systems into specific categories was proposed; secondly an in-depth analysis of existing literature was worked out to establish the methods used for different types of VGS. The study of plant physiology allowed the definition of an energy balance, which is valid for all vegetated surfaces; then, each category was associated to a mathematical formula and finally integrated into the EnergyPlus software. The results achieved for each model were compared evaluating two important parameters for the termohygrometric conditions control: outside walls face temperatures and operative temperatures.
\end{abstract}

Keywords: Vertical Greenery Systems (VGS); classification; comparison of different types of VGS; mathematical modeling and thermohygrometric analysis; EnergyPlus

\section{Introduction}

The search for technological systems and materials for urban and building regeneration, especially in recent years, has paid particular attention to sustainability. The integration between vegetation and buildings responds effectively to this request, providing benefits proven by several studies: the reduction of $\mathrm{CO}_{2}$ emissions and the high temperatures that determine the "heat island" effect, modifying the urban microclimate [1-5], the increase in the quality of life [6,7] and the improvement of building hydrological [8] and thermal performances. Vertical Greenery Systems (VGS), especially, have a great potential, as buildings in urban areas develop mainly vertically, while Green Roofs (GR) only affect the higher floors in tall buildings $[9,10]$. Furthermore, GR do not include particularly diversified systems, a feature possessed by VGS instead, which in fact require different models.

Currently, the VGS are mainly included in projects carried out by internationally renowned architects, and have very high construction and maintenance costs. For example, Stefano Boeri designed a tower completely surrounded by trees in Milan [11] and Herzog \& de Meuron integrated the Mur Vegetal, the system patented by the botanist Patrick Blanc [12], with the building envelope in their project at Caixa Forum in Madrid; the same system was chosen by Jean Nouvel for the Musée du Quai Branly in Paris. The design of systems with accessible costs, to allow a wider diffusion, can be encouraged through a more in-depth knowledge of VGS and their benefits on buildings. In fact, there are several 
technological solutions capable of providing different advantages, replacing traditional systems. The aim of the present study consists in identifying the contribution offered in the thermohygrometric field by the different types of VGS, translating the behavior of plants into a mathematical form that can be suitable for the EnergyPlus software. The validation of the methods proposed is obtained by a comparison between mathematical models and the experimental data, both as presented in the scientific literature.

\section{Classification}

The term VGS includes several systemic types that possess different characteristics and that are functional for specific plant varieties. Moreover, to build high-performance façades, it is necessary to act differently depending on the climate and the characteristics of the building [13], using the most suitable VGS. It is therefore necessary to provide a classification aimed at organizing plant verticalization into sets having common characteristics, which can be properly analyzed through accurate energy simulations and thus appreciate the differences. Some studies have proposed grouping, analyzing the scientific literature and systems characteristics, but without proposing a simulation method for each category [14-18]. On the contrary, in other research studies, such as the one conducted by Wong et al. [19], the field measurements for different VGS were analyzed but without proposing a classification.

In the present study, grouping into categories, based on the differences among the main technological solutions by considering both their geometrical and mathematical properties, is proposed. Each category has a different effect on the building envelope, based on its characteristics, through all or some of the following properties: shading, wind barrier, evaporation, transpiration and ventilated façade, as shown in Figure 1.

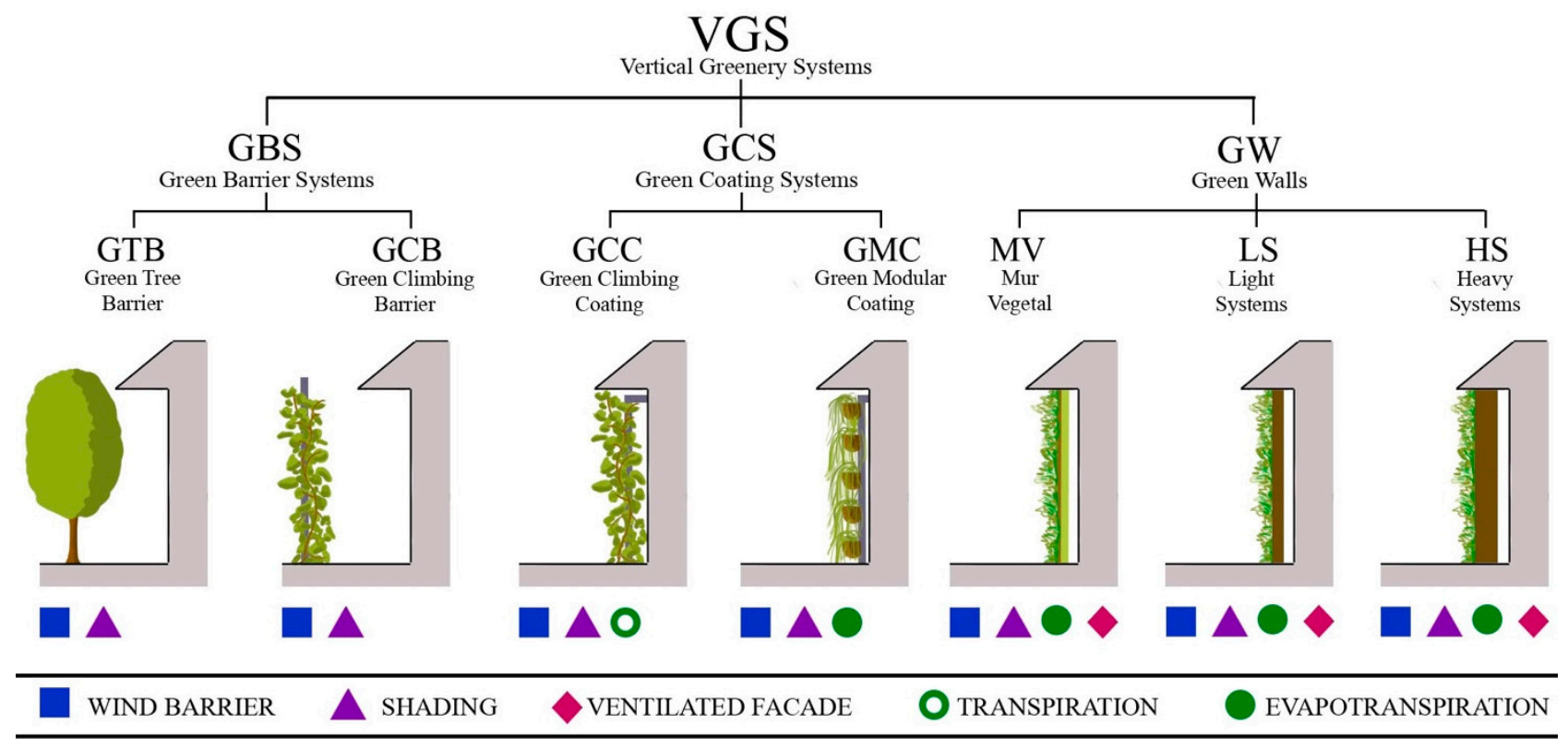

Figure 1. Proposed classification of VGS. Effects on buildings are specified for each category.

By re-elaborating the classification of VGS proposed by Bit [20], according to the energy benefits, three macro categories were defined: the Green Barrier Systems (GBS), the Green Coating Systems (GCS) and the Green Walls (GW). Each group interacts differently with the building envelope and therefore there are substantial differences in the approach to simulation. Further breaking down into sub-categories indicates differences in modeling or in the change of some parameters. GBS have the lowest level of integration with the building walls because there is no direct contact between them. The Green Barrier made up of trees (in the surroundings of the building or integrated with the structure) was defined 
as the Green Tree Barrier (GTB); systems composed by climbing species were defined as the Green Climbing Barrier (GCB).

The plant organisms that grow in adherence to a building closure or on a support system that forms a small gap with the wall were defined as the Green Coating Systems (GCS) divided into the Green Climbing Coating (GCC) and the Green Modular Coating (GMC). The main difference between these two sub-categories concerns the species of plants used: the first one is made up of climbing species and the second one consists in non-climbing species and requires particular modular systems in which a small amount of substrate is present. Finally, the Green Walls (GW) include systems which require greater technical specialization than the other categories. The technology package (which includes the plants and the substrate) is supported by a subsystem and forms a gap with the walls, thus behaving like a ventilated façade. In this case, three categories have been proposed: the Mur Vegetal (MV) that refers specifically to the system patented by the botanist Patrick Blanc [12] (in which the substrate is an inorganic fiber layer, and a PVC panel is present) and the Light Systems (LS) and the Heavy Systems (HS) that have a soil substrate and differ from each other in the soil thickness (less or greater than $15 \mathrm{~cm}$, respectively).

\section{Literature Review}

In the literature, the topic of the Vertical Greenery Systems (VGS) has been faced with both experimental studies and through numerical modeling. Nevertheless, the authors have only considered one single type of VGS at a time in simulations, and therefore, a comparison among all of the different systems with a unique method is not available. The studies analyzed investigate different areas and types: the trees shading effect [21-27], the double skin façade with plants [28-32] and the Green Walls [3,8,33-36].

Table 1 shows the most significant studies for the model developed, which have the most compatible solutions with EnergyPlus, grouping the references according to the macro-categories identified.

Table 1. Studies about VGS divided into the three categories defined. The VGS effects on buildings considered in each study are specified.

\begin{tabular}{|c|c|c|c|c|c|c|}
\hline \multirow{2}{*}{ Reference } & \multirow{2}{*}{$\begin{array}{l}\text { Author/ } \\
\text { Year }\end{array}$} & \multicolumn{3}{|c|}{ Considered Terms in Thermal Balance } & \multirow{2}{*}{$\begin{array}{c}\text { Model/ } \\
\text { Software Used }\end{array}$} & \multirow{2}{*}{ Category Analized/Method } \\
\hline & & Shading & Convection & ETP & & \\
\hline \multicolumn{7}{|c|}{ Green Barrier Systems (GBS) } \\
\hline [32] & $\begin{array}{l}\text { Stec et al. } \\
\text { (2005) }\end{array}$ & YES & YES & YES & Sim & $\begin{array}{l}\text { Green Climbing Barrier (GCB) } \\
\text { Radiative and convective thermal balances were } \\
\text { mathematically represented through the definition of } \\
\text { radiation absorption coefficient and convective heat } \\
\text { transfer coefficient, respectively. The first one was } \\
\text { found to be equal to } 0.42 \text {, according to laboratory } \\
\text { tests taken on the species Hedera helix. The second } \\
\text { one was determined using the formula proposed by } \\
\text { Stanghellini [37]: } \\
\left.N u=0.37 \text { ( } G r+6.417 \mathrm{Re}^{2}\right) \\
\text { Evapotranspiration (EPT) effect was represented } \\
\text { through the FAO Penman Monteith formula [38]: } \\
E T_{0}=\frac{0.408 \Delta *\left(R_{n}-G\right)+\gamma * T_{a}+273.15 * U_{2}\left(e_{s}-e_{a}\right)}{\Delta+\gamma\left(1+0.34 * U_{2}\right)}\end{array}$ \\
\hline [23] & $\begin{array}{l}\text { Hes et al. } \\
\text { (2011) }\end{array}$ & YES & NOT & NOT & $\begin{array}{l}\text { IES-VE } \\
\text { IES }\end{array}$ & $\begin{array}{l}\text { Green Tree Barrier (GTB) } \\
\text { Two methods to simulate tree shading were } \\
\text { proposed. The first one was modeling simplified } \\
\text { objects, compatible with the shape of a tree. The } \\
\text { changing density of the foliage was simulated } \\
\text { through three models, with } 0 \%, 50 \% \text { and } 100 \% \text { of } \\
\text { shading properties, a bare model, a perforated model } \\
\text { and an opaque one, respectively. } \\
\text { Instead, with the second method, an adjusted solar } \\
\text { absorptance coefficient was introduced directly in the } \\
\text { shaded wall properties. The adjustment considers a } \\
\text { hypothetical shadowing, as shown in the } \\
\text { following formula: } \\
\text { Adjusted Solar Absorptance }=0.6 *(1-\mathrm{SC}) \\
\text { Where SC is Shading Coefficient. }\end{array}$ \\
\hline
\end{tabular}


Table 1. Cont.

\begin{tabular}{|c|c|c|c|c|c|c|}
\hline \multirow{2}{*}{ Reference } & \multirow{2}{*}{$\begin{array}{l}\text { Author/ } \\
\text { Year }\end{array}$} & \multicolumn{3}{|c|}{ Considered Terms in Thermal Balance } & \multirow{2}{*}{$\begin{array}{c}\text { Model/ } \\
\text { Software Used }\end{array}$} & \multirow{2}{*}{ Category Analized/Method } \\
\hline & & Shading & Convection & ETP & & \\
\hline [31] & $\begin{array}{l}\text { Larsen et al. } \\
\quad(2014)\end{array}$ & YES & YES & NOT & Ene & $\begin{array}{l}\text { Green Climbing Barrier (GCB) } \\
\text { Two different shading elements were used: Building } \\
\text { Shading Object (BS) and Window Shading Device } \\
\text { Object (WSD). To consider the wind barrier effect of } \\
\text { the model, the convective heat exchange coefficient is } \\
\text { calculated as proposed by [32]: } \\
N u=0.37\left(G r+6.417 R^{2}\right)^{0.25} \\
\text { The modification of the view factor of the walls and } \\
\text { windows is also proposed to take into account the } \\
\text { diffused solar radiation reflected from the ground. }\end{array}$ \\
\hline \multicolumn{7}{|c|}{ Green Coating Systems (GCS) } \\
\hline [28] & $\begin{array}{l}\text { Yoshimi and } \\
\text { Altan } \\
\text { (2011) }\end{array}$ & YES & YES & NOT & & $\begin{array}{l}\text { Green Climbing Coating (GCC) } \\
\text { The evapotranspiration effect was greatly simplified, } \\
\text { by modeling a layer of water vapor above the leaf } \\
\text { layer that represents the water evaporated from the } \\
\text { leaves. The thermal model of the species Hedera } \\
\text { helix (Common Ivy) species is composed of } 5 \text { layers: } \\
\text { water vapour, leaves, air gap, softwood (stem) and } \\
\text { another air gap; the thermal properties are defined } \\
\text { for each one. } \\
\text { (ECOTECT Is not available any more as a stand } \\
\text { alone tool) }\end{array}$ \\
\hline \multicolumn{7}{|c|}{ Green Walls (GW) } \\
\hline [8] & $\begin{array}{l}\text { Malys et al. } \\
\text { (2014) }\end{array}$ & YES & YES & YES & $\begin{array}{l}\text { Self-developed } \\
\text { model in } \\
\text { SOLENE- } \\
\text { Microclimate }\end{array}$ & $\begin{array}{l}\text { Heavy System (HS) } \\
\text { The hydrothermal model, validated with field } \\
\text { measurements, represents each layer as a node and } \\
\text { each node is associated with a thermal or water } \\
\text { balance. In addition, a parametric study was } \\
\text { conducted: nine variable parameters were used to } \\
\text { characterize the substrate and leaf layer. The quality } \\
\text { of the combinations of parameters was determined } \\
\text { by calculating the root of the mean square error. }\end{array}$ \\
\hline [36] & $\begin{array}{l}\text { Scarpa et al. } \\
\quad(2014)\end{array}$ & YES & YES & YES & $\begin{array}{l}\text { Self-developed } \\
\text { mathematical } \\
\text { model }\end{array}$ & $\begin{array}{l}\text { Mur Vegetal (MV) } \\
\text { The Green Wall was divided into } 11 \text { thermal nodes; } \\
\text { the behavior of each one was described with a } \\
\text { thermal balance equation. The thickness of the cavity } \\
\text { behind the system was also considered, evaluating its } \\
\text { type (ventilated or not). The model shows a good } \\
\text { agreement with the field measurement realized. }\end{array}$ \\
\hline [34] & $\begin{array}{c}\text { Dahana-yake } \\
\text { e Chow } \\
\text { (2017) }\end{array}$ & YES & YES & YES & $\begin{array}{c}\text { Self-developed } \\
\text { model } \\
\text { integrated in } \\
\text { EnergyPlus }\end{array}$ & $\begin{array}{l}\text { Light System (LS) } \\
\text { The heat balance equations of the model are based on } \\
\text { the Green Roof module present in the EnergyPlus } \\
\text { [39,40], on the FASST model proposed by } \\
\text { Frankenstein and Koenig [41] and on the } \\
\text { hydrothermal model validated by Malys et al. [8]. } \\
\text { The correlation coefficients are close to unity, } \\
\text { showing a good match between the simulation } \\
\text { results and those of the experimental case. }\end{array}$ \\
\hline [35] & $\begin{array}{l}\text { Djedji et al. } \\
\text { (2017) }\end{array}$ & YES & YES & YES & $\begin{array}{l}\text { Self-developed } \\
\text { model } \\
\text { integrated in } \\
\text { TRNSYS }\end{array}$ & $\begin{array}{l}\text { Heavy System (HS) } \\
\text { The mathematical model used was developed on the } \\
\text { basis of a green roof model, analyzed by the authors } \\
\text { in a previous study [ } 42 \text { ], analyzing solar and infrared } \\
\text { radiation, convection and evapotranspiration. } \\
\text { The validation of the analytical model of the green } \\
\text { wall is based on the comparison of the external } \\
\text { surface temperature of the substrate with that of a } \\
\text { monitored green roof. }\end{array}$ \\
\hline
\end{tabular}

From Table 1, it is evident that all the mentioned studies consider just one type of VGS at time performing numerical analyses with diverse codes that evaluate different terms in thermal balance. Therefore, a consistent comparison among different VGS systems cannot be properly evaluated. 


\section{Methodology}

The mathematical model used in this study was obtained by integrating some of the formulas analyzed in the literature review into EnergyPlus. The equations used have already been validated by previous research and are reported and specifically defined in Section 4.1. Then, according to the effects on buildings indicated in Figure 1, the components of the energy balance were integrated into the numerical code of the software, as presented in Section 4.2.

\subsection{Study of Plant Physiology}

The analysis of several studies and publications regarding plant physiology [37-51] allowed the determination of the energy balances that occur on the surface of plants.

Vegetated surfaces interact with the environment through energy exchange, basically involving four terms: net radiation $R_{\mathrm{n}}$, sensible heat flux $H$, heat flux through soil $G$ and latent heat flux $L$, that are linked together by the balance proposed by FAO [38]. In particular, $G$ value is negligible on daily averages [34,38]. Moreover, the physical characteristics of the leaves influence the energy balance on vegetated surfaces [43], so the main parameters were analyzed.

\subsubsection{Radiation Balance}

Net radiation is the difference between incoming and outgoing radiation, considering both shortwave and longwave radiation [47]. It can be defined as the difference between net solar radiation and net longwave radiation:

$$
R_{n}=R_{n s}-R_{n l}
$$

and typically takes on a positive value during the day and a negative one at night. Net solar radiation $R_{n s}$ is the percentage of radiation that is not reflected by the surface, and its value is therefore related to albedo by the following relation, as leaves are primarily absorptive [47]:

$$
R_{n s}=(1-\alpha) * R_{s}
$$

where albedo $(\alpha)$ depends on different variables like density, thickness and the color of leaves [43].

The solar radiation transmitted to soil, beyond the foliage layer, was calculated according to the following equation:

$$
R_{n s}=(1-\alpha) * R_{s} * e^{-k_{s} * L A I}
$$

that considers the geometrical properties of canopy.

\subsubsection{Sensible Heat Flux}

The energy exchange on a surface, due to sensible heat flux, is perceived as an increase or decrease in surface temperature. Heat transport occurs through convection, and after a comparison (using the EnergyPlus simulation program) with other studies [37,43,52], the mathematical formula proposed by Stec et al. [32] appears as the one that best fits what is stated by FAO [38]:

$$
N u=0.37\left(G r+6.417 R e^{2}\right)^{0.25}
$$

where $N u, G r$ and Re are, respectively, the Nusselt, the Grashof and the Reynolds number. Thus, the convective heat transfer coefficient $h$ can be expressed as follows:

$$
h=\frac{k}{N u \cdot L}
$$




\subsubsection{Latent Heat Flux}

Latent heat flux allows a substance to affect a state change, by adding heat, without perceiving an increase in the temperature of the substance itself [47]. This type of heat exchange characterizes the vegetated surfaces: water vaporizes thanks to the transpiration from the leaves and evaporation from the ground. The whole process is known as evapotranspiration and results in a cooling effect of the surroundings [8,34,41]. Mass and energy flows are related by the following equation:

$$
L=\lambda * E T
$$

where $L$ is the latent heat flux, $\lambda$ is the latent heat of vaporization, and $E T_{0}$ is the evapotranspiration value, starting from the FAO Penman-Monteith equation [38], adapted to VGS by Davis and Hirmer [49]:

$$
E T_{0}=\frac{0.408 \Delta *\left(R_{n}-G\right)+\gamma * \frac{900}{T_{a}+273.15} * U_{2}\left(e_{s}-e_{a}\right)}{\Delta+\gamma\left(1+0.34 * U_{2}\right)}
$$

To obtain the evapotranspiration value $E T$ for a particular plant species, $E T_{0}$ value is multiplied by coefficient $K_{C}$, depending on the plant species [36,38].

\subsubsection{Physical Parameters of Leaves}

The physical characteristics of plants that influence the energy balance with the environment are essentially the LAI (Leaf Area Index) $[53,54]$ and extinction coefficient $k_{s}$ that depends on the spatial distribution of leaves and on the angle between the leaves and soil. Both these parameters contribute to the result of Equation (3).

\subsection{Integration in the EnergyPlus}

The use of a software that operates in dynamic regime is necessary to guarantee a simulation as close as possible to reality related to plant organisms, which are a living component of the building envelope and therefore respond to environmental conditions in a very complex way. The use of advanced programming language, the EnergyPlus runtime language (Erl) combined with the Energy Management System (EMS), and other functions integrated into the software make it possible to simulate every component of the energy balance on vegetated surfaces. EnergyPlus provides a model (EcoRoof Model [31]) to simulate greenery systems, but it works only for horizontal vegetated surfaces, and it does not consider the change of the emissivity values of foliage and soil and of the convective heat transfer coefficient, both influenced by the inclination of the analyzed surface.

\subsubsection{The EMS Settings-The Solar Absorptance}

The leaves can absorb long-wave radiation almost completely, so they are considered as perfect emitters [47]; consequently, the thermal absorptance value is equal to 1 . Instead, the solar absorptance coefficient $(\zeta)$ depends on the specie's physical characteristics, according to [43]:

$$
\zeta=1-e^{-k_{s} * L A I}-\alpha
$$

and for each parameter a variation range was defined (Table 2).

Table 2. Variation range for the variable parameters that influence solar absorptance coefficient and related references.

\begin{tabular}{ccc}
\hline Variable Parameters & Variation Range & Reference \\
\hline$k_{s}$ & $0.16-1$ & {$[51]$} \\
$L A I$ & $0.30-5$ & {$[53]$} \\
$\alpha$ & $0.20-0.25$ & {$[38]$} \\
\hline
\end{tabular}


The reference species, Bergenia Crassifolia and Geranium Macrorrhizum were associated with a LAI equal to 2.24 and 1.89 , respectively. These values were obtained by the comparison with similar species analyzed by Candelari [55].

Equation (5) was integrated in the EMS, setting the solar absorptance coefficient as an actuator (i.e., value affected by programming) and the other variables in the formula as sensors (i.e., input values).

\subsubsection{The EMS Settings-The Sensible Heat Flux}

Sensible heat flux related to VGS was simulated using EMS, this time setting the convective heat transfer coefficient as an actuator. Analyzing different methods proposed in the literature $[23,24,43,52]$, and comparing the daily sensible heat flux values obtained with the values of the other terms involved in the energy balance [38], the formula proposed by Stec et al. [32] resulted as the most suitable as reported above in Equation (4).

\subsubsection{The Advanced Settings-The Latent Heat Flux}

The EnergyPlus, among its advanced settings, provides the possibility to add another term to the traditional energy balance on the outer or inner surface of a wall. This function was to simulate the evapotranspiration effect. The hourly latent heat flux was calculated according to Equation (7). Different values of coefficient $K_{C}$ were used to represent different plant species [34] to compare the related ET term.

\subsubsection{The Advanced Settings-The Ventilated Façade}

The Green Walls can be compared to a ventilated façade, due to the gap between the continuous surface of these systems and the building envelope. This effect was never considered in developing GW's models, despite having a significant effect in summer energy efficiency. Analyzing some studies about these systems [56-58] and their simulation methods in the EnergyPlus [39], the most suitable model was defined. The ventilated cavity was modeled as a separate thermal zone, and the setting Zone Ventilation: Wind and Stack Open Area was applied. This function allows the automatic calculation of the convective heat fluxes in the gap, considering wind and stack effects.

\subsubsection{The Layers' Properties}

The Green Walls were represented as a simplified model, composed of two layers: foliage and substrate, spaced from the wall by an air gap. The foliage properties are different for each plant species, so two reference species have been analyzed: Geranium Machrorrhizum, associated with Light Systems because of its superficial roots, and Bergenia Crassifolia, linked to Heavy Systems because of the roots developing in depth. Thermal and physical properties were attributed to these layers comparing the results obtained by Jayalakshmy and Philip [45] and Merzlyak et al. [46] for some plant species' leaves. Table 3 shows the properties obtained for the two reference species.

The study of the thermophysical properties of the soil, whose contribution is substantial due to its thermal mass, was carried out after a literature review [59-65]. Three types of soil have been analyzed in this study: sandy loam, loam and clay loam, suitable for cultivation, and for each one, a defined density was fixed, thermal conductivity and specific heat. For the two species selected, the composition of soil was chosen according to the plant considered, to ensure its proper growth. The properties of soil are related to its water content, that must be included in a specific range to allow the plants to fulfill their vital functions: between $5 \%$ and $10 \%$ for sandy soils and between $40 \%$ and $50 \%$ for clay soils, as stated by Pitts [65]. These values were used to find a linear correlation between sandy and clay soils, to identify the correct saturation percentage of the simulated soils as shown in Figure 2. 
Table 3. Variation range for the variable parameters that influence solar absorptance coefficient and related references.

\begin{tabular}{cccc}
\hline Properties & Units & $\begin{array}{c}\text { Bergenia } \\
\text { Crassifolia }\end{array}$ & $\begin{array}{c}\text { Geranium } \\
\text { Macrorrhizum }\end{array}$ \\
\hline Single leaf thickness & $\mathrm{m} \cdot 10^{-3}$ & 0.25 & 0.21 \\
\hline Canopy layer thickness & $\mathrm{m} \cdot 10^{-3}$ & 5 & 5 \\
\hline Thermal conductivity & $\mathrm{W} \cdot \mathrm{m}^{-1} \cdot \mathrm{K}^{-1}$ & 0.34 & 0.35 \\
\hline Density & $\mathrm{kg} \cdot \mathrm{m}^{-3}$ & 656 & 627 \\
\hline Specific heat & $\mathrm{J} \cdot \mathrm{kg}-1 \cdot \mathrm{K}^{-1}$ & 2252 & 2232 \\
\hline Thermal effusivity & $\mathrm{W} \cdot \mathrm{s}^{\frac{1}{2}} \cdot \mathrm{m}^{-2} \cdot \mathrm{K}^{-1}$ & 714 & 702 \\
\hline Thermal diffusivity & $\mathrm{m}^{2} \cdot \mathrm{s}^{-1} \cdot 10^{-6}$ & 0.23 & 0.25 \\
\hline
\end{tabular}

Other properties related to each soil, were obtained analyzing the studies carried out by Clauser and Huenges [61], Abu-Hamdeh and Reeder [59] and Monteith and Unsworth [50]; the results are shown in Table 4.

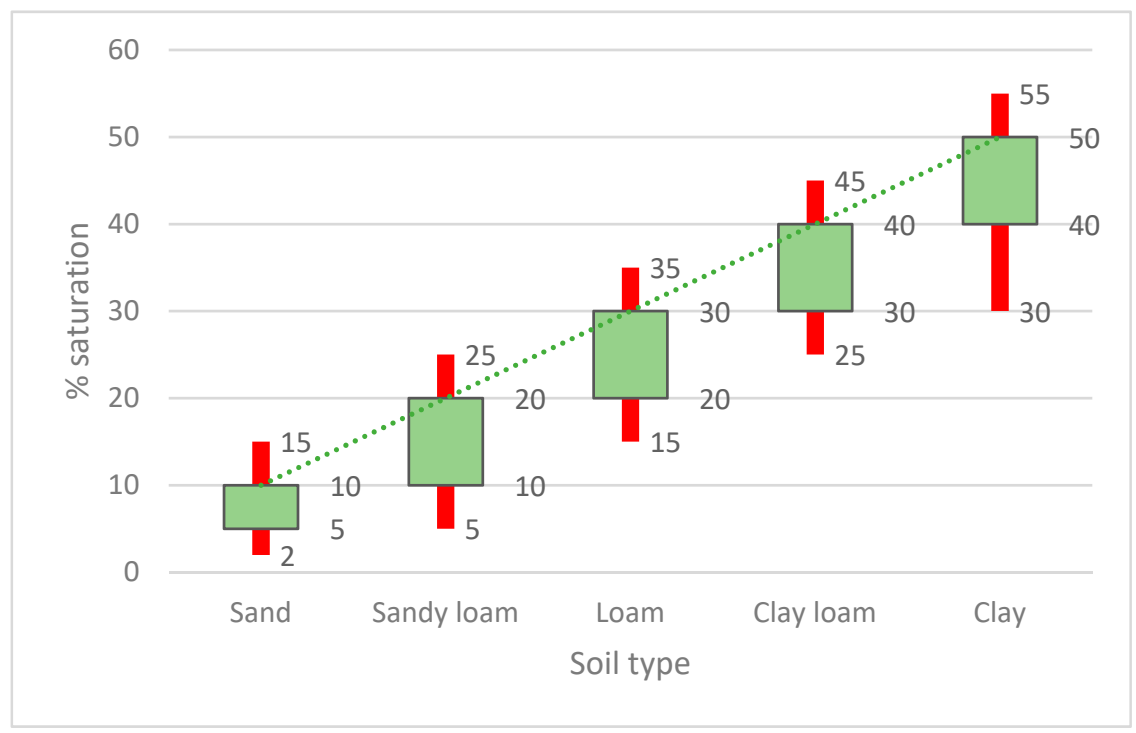

Figure 2. The optimal range of saturation percentage for each type of soil, to guarantee plant survival, is represented by the rectangular boxes; instead, the values indicated as a line generate stress in plants.

Table 4. Properties of cultivated soil (sandy loam, loam, clay loam) related to saturation percentage of pores.

\begin{tabular}{|c|c|c|c|c|c|c|c|}
\hline \multirow{4}{*}{$\begin{array}{c}\text { Properties } \\
\% \text { Saturation }\end{array}$} & \multirow{4}{*}{$\begin{array}{c}\text { Units } \\
-\end{array}$} & \multicolumn{3}{|c|}{ Bergenia Crassifolia } & \multicolumn{3}{|c|}{ Geranium Macrorrhizum } \\
\hline & & \multicolumn{2}{|c|}{ Sandy loam } & \multicolumn{2}{|c|}{ Loam } & \multicolumn{2}{|c|}{ Clay loam } \\
\hline & & $\min$ & $\max$ & $\min$ & $\max$ & $\min$ & $\max$ \\
\hline & & 10 & 20 & 20 & 30 & 30 & 40 \\
\hline Density & $\frac{\mathrm{kg}}{\mathrm{m}^{3}}$ & 1700 & 1800 & 1800 & 1900 & 1900 & 2000 \\
\hline Thermal conductivity & $\frac{\mathrm{W}}{\mathrm{m} \cdot \mathrm{K}}$ & 1.26 & 2.03 & 1.02 & 1.22 & 1.34 & 1.45 \\
\hline Specific heat & $\frac{\mathrm{J}}{\mathrm{kg} \cdot \mathrm{K}}$ & 1125 & 1328 & 1080 & 1209 & 1324 & 1465 \\
\hline
\end{tabular}




\subsection{Mathematical and Geometrical Models}

Each category above defined was simulated in the EnergyPlus using simple models, by adopting small cubic samples $(3 \times 3 \times 3 \mathrm{~m})$ with $15 \mathrm{~cm}$ concrete walls. The concrete cubic sample was used as reference model in the comparisons with each category. The analysis of these models allowed the comparison between VGS categories and the execution of a large number of tests, avoiding the simulation of complex buildings. The dynamic simulations were performed in a free running mode, without plants. The meteorological data used refer to the Brescia-Ghedi weather file [66].

From the geometric point of view, GBS were modeled as shading objects: simplified trees for GTB and rectangular surfaces for GCB, both placed at a distance of $2 \mathrm{~m}$ from the walls of the sample. A transmittance schedule was associated with each shading object, to represent the different transmission of solar radiation in each season.

GCS were simulated adding two layers on the outer sample's surfaces: an anti-root membrane and a vegetated layer. The subcategory GMC also has a small layer of substrate, but its contribution can be negligible in terms of thermal insulation. In addition to the modification of the layers' properties, the behavior of the plants was reproduced through the modification of the solar absorptance, of the sensible heat flux and by adding the latent heat contribution. The latter, for the GCC only results from foliage transpiration, while for the GMC results from the whole process of evapotranspiration, due to the presence of soil.

The GW have the common feature of functioning as ventilated façades, and they were simulated as described in 4.2.4. The MV has a defined stratigraphy, and the outer layer was simulated respecting the characteristics of the system patented by Patrick Blanc [12]. The HS and LS can be composed of different types of plants and substrates, which determine a great variability in the results. Therefore, a parametric study was carried out to identify the most effective combination of variables in improving the thermohygrometric behavior of the sample. The parameters were analyzed one at a time, keeping the other characteristics of the system unchanged and applying only the setting concerning that specific variable. The variation of the extinction coefficient $k_{s}$, the thickness of the air gap and the type of soil appears to be almost irrelevant in influencing the external surface temperatures; while the variation of LAI, as shown in Figure 3, influences the external surface temperatures which is reduced by about $2{ }^{\circ} \mathrm{C}$ in summer for a LAI equal to 5 compared to a LAI equal to 1 , comparable to the results obtained by [43].

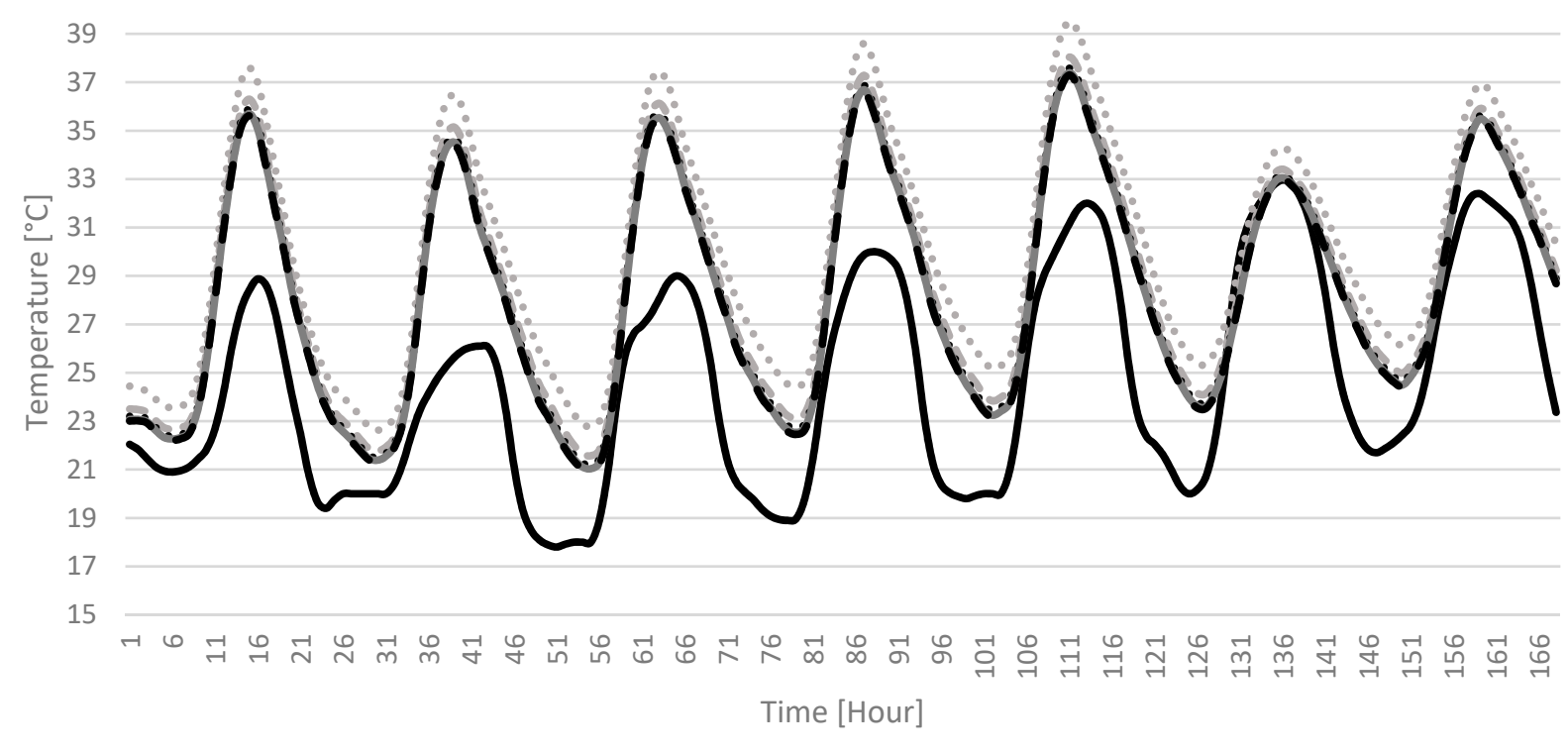

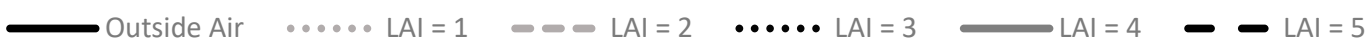

Figure 3. Effect of LAI on the surface external temperature of the walls. Model properties: Substrate in Loam (9 cm); $k_{\mathrm{S}}=0.70$; air gap thickness $=4 \mathrm{~cm}$. 


\section{Results and Discussion}

The overall assessment of the thermohygrometric benefits on the simulated model was made by comparing the results obtained for the VGS models and the reference concrete model, analyzing external surface temperatures and operative temperatures, both in summer and winter. All the graphs refer to the south-facing walls, and the physical parameters used are consistent with the species suitable for the different systems, as indicated above and in [67].

The trends of outside face temperature for each category and for the concrete model, compared with outside air temperature, are shown in Figures 4 and 5, in summer and winter conditions, respectively.

The summer chart shows the data obtained during the simulation performed in the last week of July (25-31/07), the hottest day of the summer according to the meteorological data analysis [66].

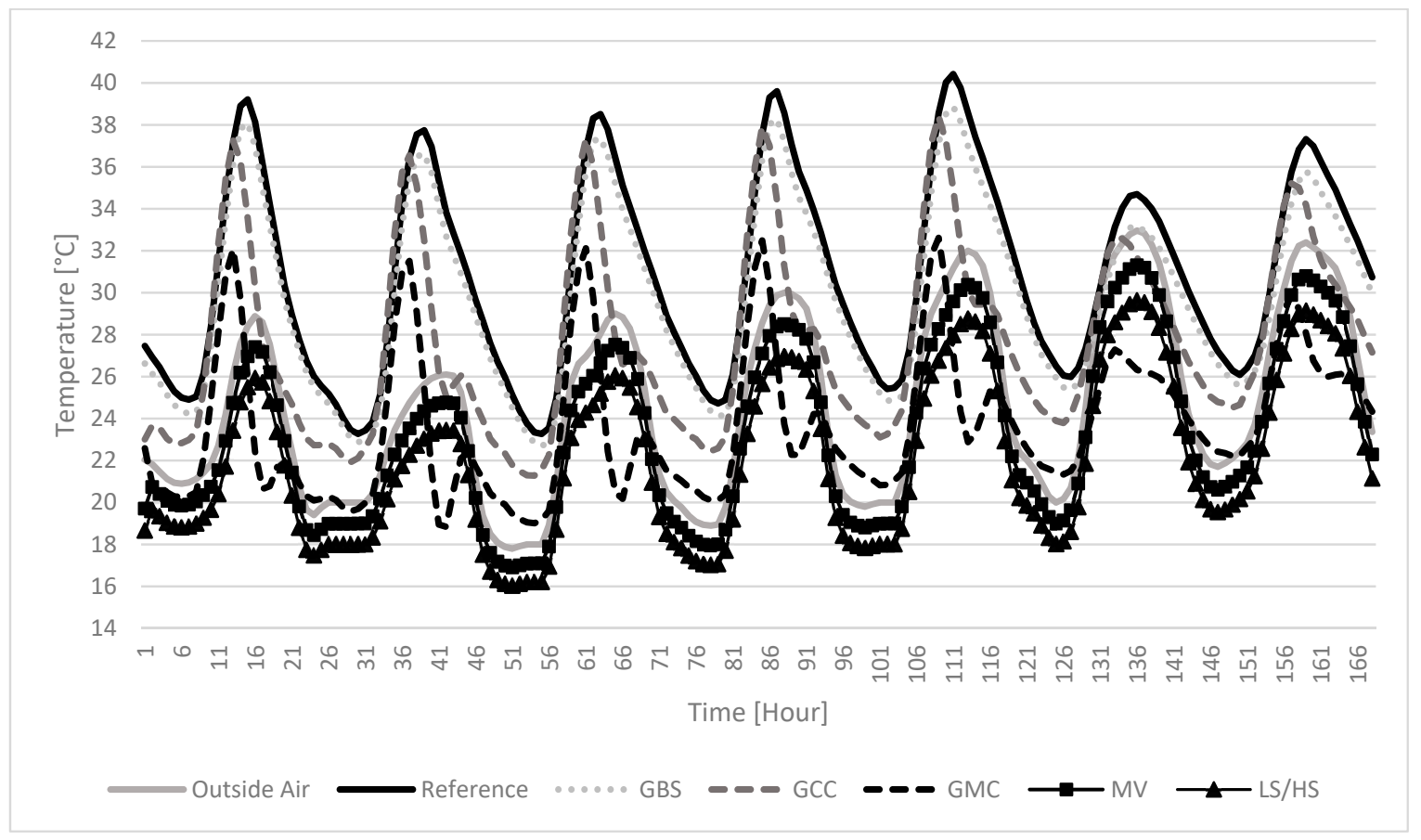

Figure 4. Summer (25-31/07). Comparison between the external surface temperatures of the south wall for each category, the concrete model and outside air.

The GBS reduce concrete surface outside face temperatures by about $1.5^{\circ} \mathrm{C}$, due to the shading effect of trees and climbing species. There are no significant differences in the trends of the GTB and GCB models as both act only through shading and do not influence the temperature of the wall with the transpiration process. Hes [23] and Stec et al. [32] instead reported up to a $25 \%$ reduction in the outside surface temperatures for the GBS. The Different results could be due to the different height and position of the trees or climbing species or to a greater window area of the analyzed model. The GCC reduce the temperature of the concrete model on average by about $5^{\circ} \mathrm{C}$, confirmed by the empirical results obtained by [68], and the GMC by about $6^{\circ} \mathrm{C}$, due to the presence of soil, which also adds the evaporation process. The GW systems remarkably reduce the surface temperatures, also lower than the ones of outside air. The most performing systems are the LS and HS that reduce the maximum temperature of the concrete model up to $13{ }^{\circ} \mathrm{C}$, included in the range of values obtained by Mazzali et al. [69]. These systems record higher evaporation values from the soil, having thick and continuous layers. 


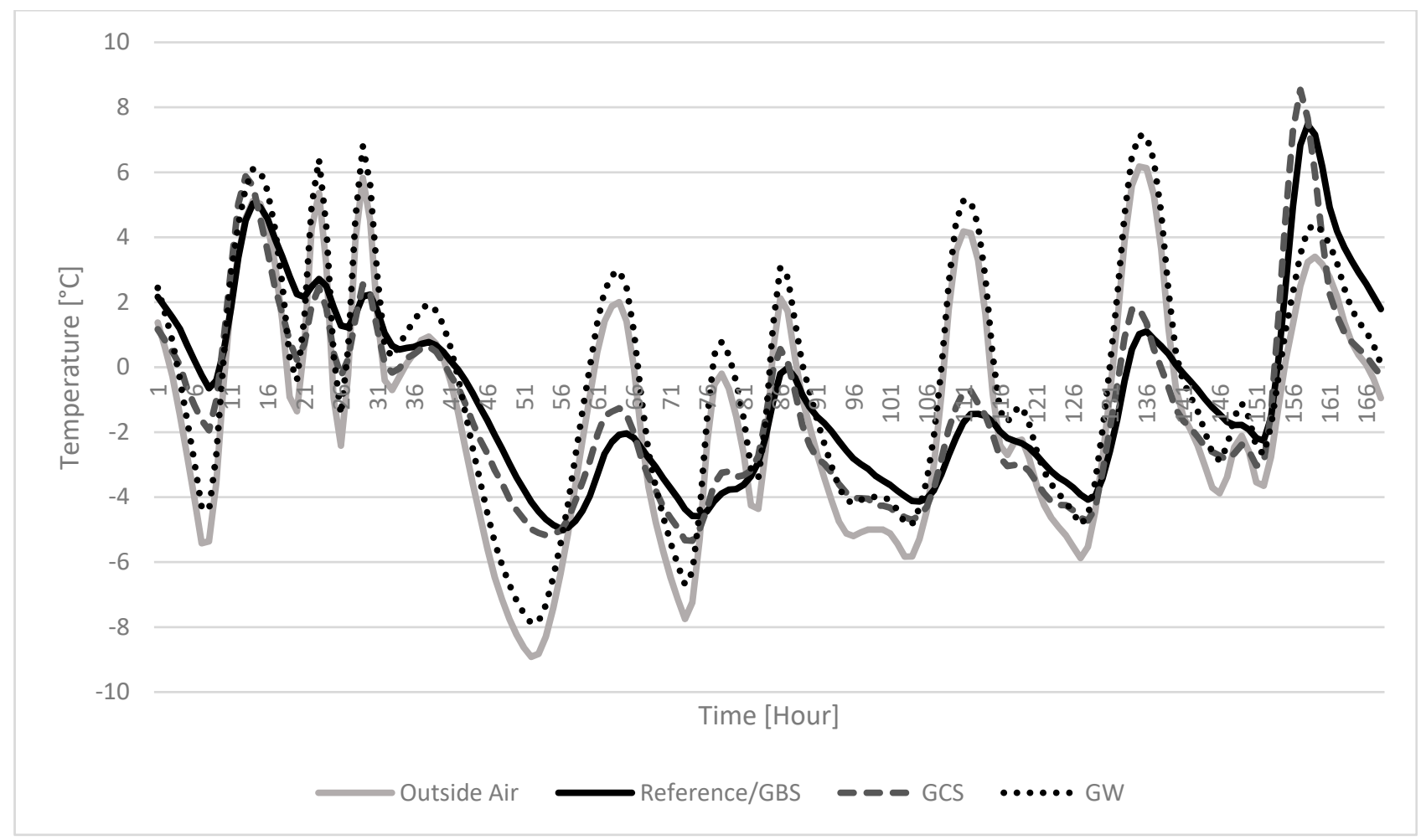

Figure 5. Winter (01-07/12). Comparison between the external surface temperatures of the south wall for each category, the concrete model and outside air.

The winter chart shows the data obtained during the simulation performed in the first week of December (01-07/12), the coldest day of the year. The trend of the external surface temperature of the GBS coincides with that of the bare wall, as in this season they only act as wind barriers; the latter effect could be more relevant with denser vegetation. The GCS increase the surface temperature by about $1{ }^{\circ} \mathrm{C}$ on average, during the day, similarly to the results obtained by [70], as they have a better behavior as wind barriers. The GW, instead, follow the trend of the outside air temperature, with negligible variations, increasing the external surface temperature up to $8^{\circ} \mathrm{C}$ higher than the reference. No simulations were found in the winter period comparable with those carried out.

The influence of the different models on the summer and winter operative temperature is shown in Figures 6 and 7, respectively.

In summer (Table 5), the HS have the most significant impact in lowering the operative temperature: up to $9^{\circ} \mathrm{C}$ less than the concrete model. These results derive from the higher thermal mass of the soil and from a higher LAI value than the other systems; in fact, the HS, thanks to the high thickness of the substrate, can host larger species and therefore greater foliar density. The LS, MV and GMC have similar trends, with a reduction in peak temperatures of between 4 and $8{ }^{\circ} \mathrm{C}$, similarly to the field measurement on a living wall made by [71]. In these cases, the thermal mass of the soil, being less thick, has less effect on lowering temperatures. The GCC lower the temperatures between 3 and $6{ }^{\circ} \mathrm{C}$, decreasing temperatures thanks to the transpiration of the foliage and shading. The GBS generally do not show a significant lowering in air temperature [72,73], even if in two of the days analyzed, there is a reduction in temperature of up to $4{ }^{\circ} \mathrm{C}$, due to shading.

The best performing system in winter (Table 6) is the MV, which has $15 \mathrm{~cm}$ thick PVC panels in its stratigraphy, with a thermal conductivity lower than that of the soil, which allows a better insulation than the other systems; the operative temperature increases up to $4{ }^{\circ} \mathrm{C}$ compared to the bare wall. The LS and HS increase the operative temperature by about 1 and $2{ }^{\circ} \mathrm{C}$, respectively, compared to the concrete model. In these systems, the soil provides thermal resistance but, being almost always wet, does not have a low enough 
thermal conductivity to be insulating. The GCS have a very similar trend to that of the concrete model and the GBS trend coincides with the latter, as they shelter from the cold winter wind but do not isolate the wall.

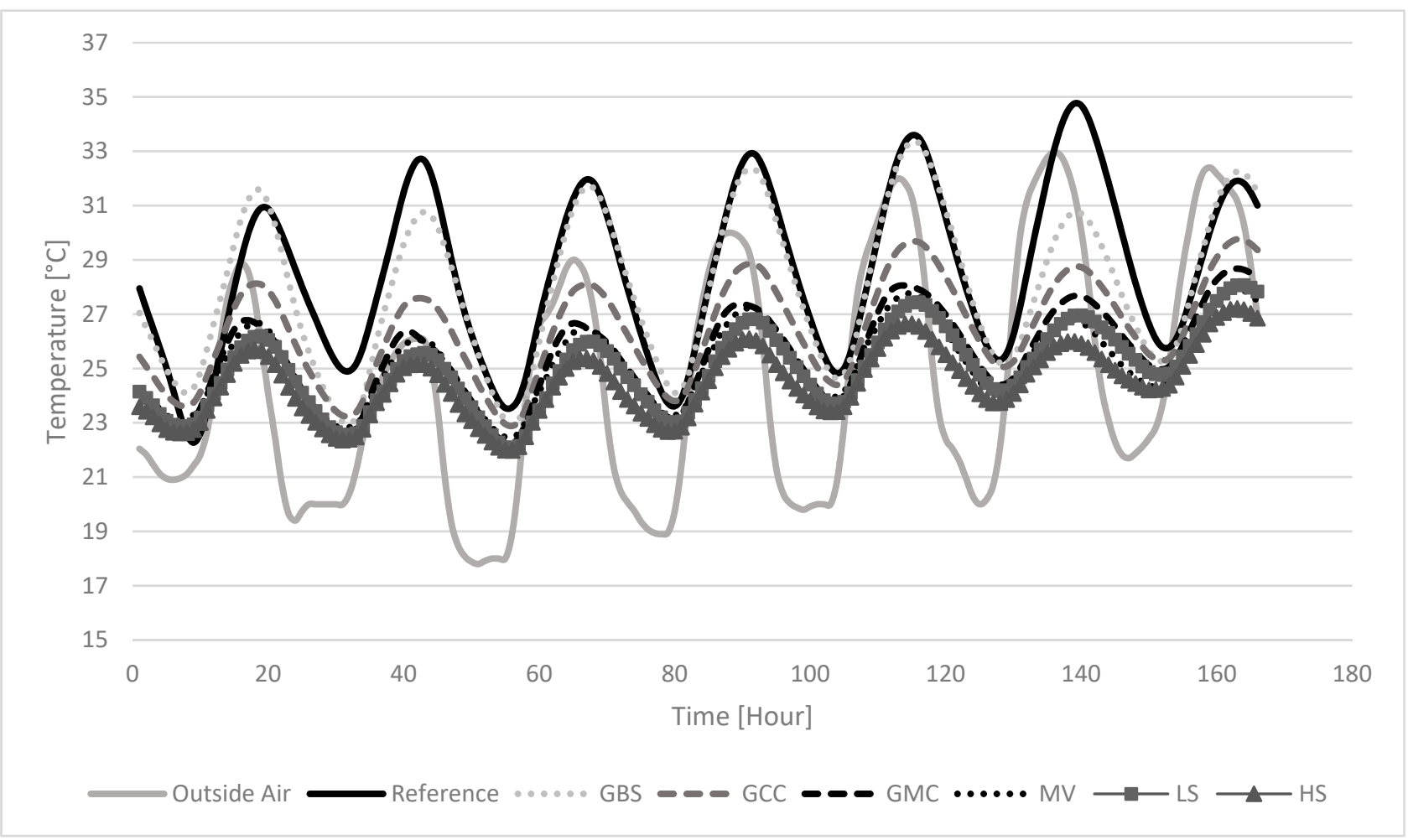

Figure 6. Summer. Comparison between the operative temperatures obtained for each category and outside air.

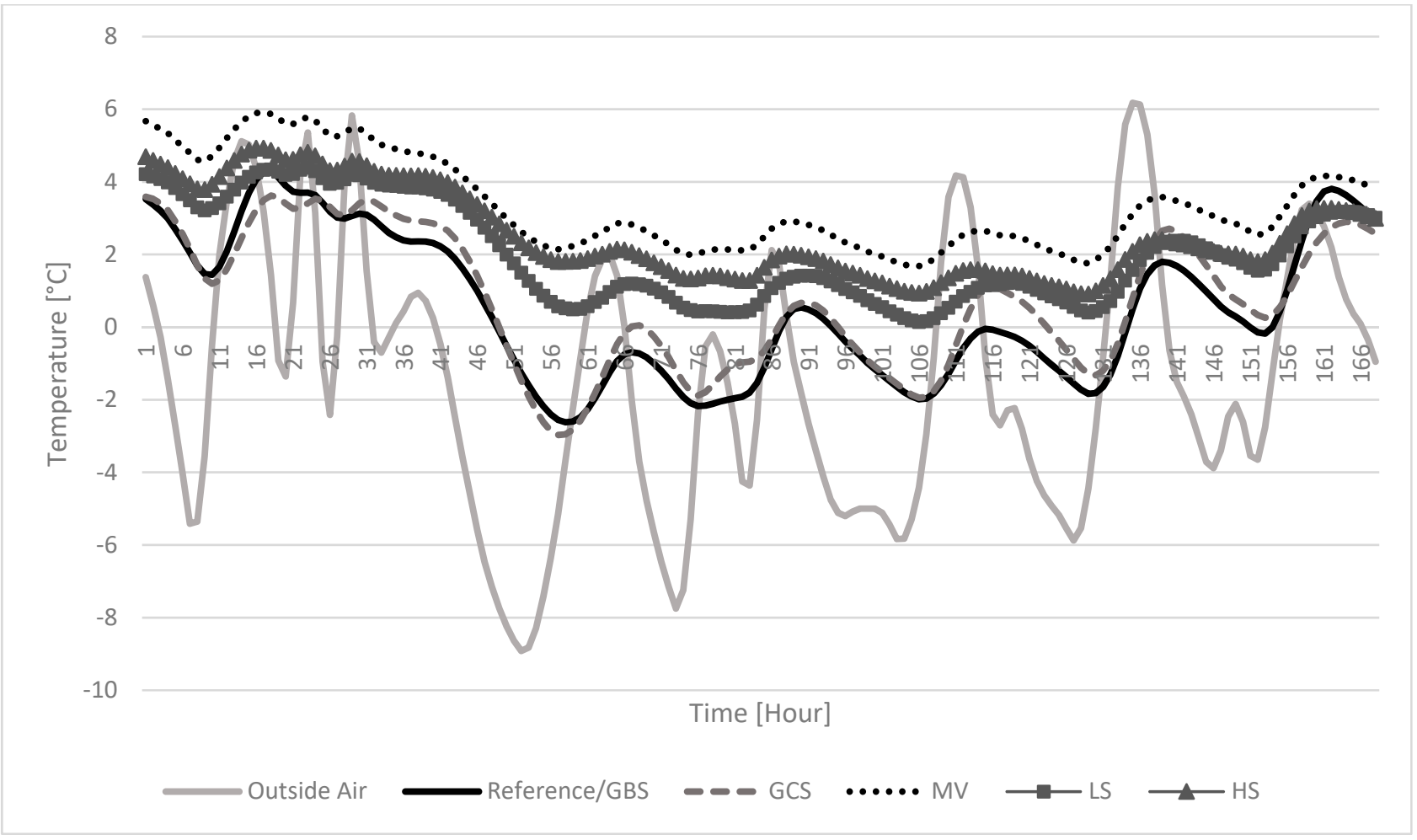

Figure 7. Winter. Comparison between the operative temperatures obtained for each category and outside air. 
Table 5. Summer. Comparison of the results obtained on the south wall of the sample during the daytime and evaluation of the main variables involved for each category.

\begin{tabular}{cccc}
\hline VGS & $\begin{array}{c}\text { Maximum Reduction of } \\
\text { the External Surface } \\
\text { Temperature Compared to } \\
\text { the Reference Sample }\end{array}$ & $\begin{array}{c}\text { Maximum Reduction of } \\
\text { the Operative } \\
\text { Temperature Compared to } \\
\text { the Reference Sample }\end{array}$ & Main Effects Involved \\
\hline GTB & $-1.5^{\circ} \mathrm{C}(-4 \%)$ & $-4{ }^{\circ} \mathrm{C}(-11 \%)$ & Shading \\
\hline GCB & $-1.5^{\circ} \mathrm{C}(-4 \%)$ & $-4{ }^{\circ} \mathrm{C}(-11 \%)$ & Shading \\
\hline GCC & $-5{ }^{\circ} \mathrm{C}(-12 \%)$ & $-6{ }^{\circ} \mathrm{C}(-17 \%)$ & Shading/transpiration \\
\hline GMC & $-6{ }^{\circ} \mathrm{C}(-15 \%)$ & $-7.5{ }^{\circ} \mathrm{C}(-21 \%)$ & Shading/evapotranspiration \\
\hline MV & $-10{ }^{\circ} \mathrm{C}(-26 \%)$ & $-8{ }^{\circ} \mathrm{C}(-23 \%)$ & Evapotranspiration/Ventilated façade \\
\hline LS & $-13{ }^{\circ} \mathrm{C}(-32.5 \%)$ & $-8{ }^{\circ} \mathrm{C}(-23 \%)$ & Evapotranspiration/Ventilated façade \\
\hline HS & $-13{ }^{\circ} \mathrm{C}(-32.5 \%)$ & $-9{ }^{\circ} \mathrm{C}(-26 \%)$ & Evapotranspiration/Ventilated façade \\
\hline
\end{tabular}

Table 6. Winter. Comparison of the results obtained on the south wall of the sample during the daytime and evaluation of the variables involved for each category.

\begin{tabular}{cccc}
\hline VGS & $\begin{array}{c}\text { Maximum Increase of the } \\
\text { External Surface } \\
\text { Temperature Compared to } \\
\text { the Reference Sample }\end{array}$ & $\begin{array}{c}\text { Maximum Increase of the } \\
\text { Operative Temperature } \\
\text { Compared to the } \\
\text { Reference Sample }\end{array}$ & Main Effects Involved \\
\hline GTB & $\pm 0{ }^{\circ} \mathrm{C}( \pm 0 \%)$ & $\pm 0{ }^{\circ} \mathrm{C}( \pm 0 \%)$ & Wind barrier \\
\hline GCB & $\pm 0{ }^{\circ} \mathrm{C}( \pm 0 \%)$ & $\pm 0{ }^{\circ} \mathrm{C}( \pm 0 \%)$ & Wind barrier \\
\hline GCC & $+1{ }^{\circ} \mathrm{C}(+13 \%)$ & $+1{ }^{\circ} \mathrm{C}(+67 \%)$ & Wind barrier \\
\hline GMC & $+1{ }^{\circ} \mathrm{C}(+13 \%)$ & $+1{ }^{\circ} \mathrm{C}(+67 \%)$ & Wind barrier \\
\hline MV & $+8{ }^{\circ} \mathrm{C}(+800 \%)$ & $+4{ }^{\circ} \mathrm{C}(+200 \%)$ & $\begin{array}{c}\text { PVC panel in the } \\
\text { stratigraphy }\end{array}$ \\
\hline LS & $+8{ }^{\circ} \mathrm{C}(+800 \%)$ & $+1{ }^{\circ} \mathrm{C}(+100 \%)$ & Soil thermal conductivity \\
\hline HS & $+8{ }^{\circ} \mathrm{C}(+800 \%)$ & $+2{ }^{\circ} \mathrm{C}(+150 \%)$ & Soil thermal conductivity \\
\hline
\end{tabular}

\section{Conclusions}

The subdivision of the VGS into categories turned out to be a fundamental step in setting up the entire work, allowing to compare the advantages of using different VGS. The variations in modeling and in the attribution of diversified energy balances on the same sample building allowed comparison of results about trends of the external surface temperatures and the operative temperatures for each system. The in-depth literature review produced mathematical models and allowed comparison of the results with those from empirical studies, demonstrating a good match. The HS (with a consistent substrate thickness) proved to be the best performing in the summer season, while the Mur Vegetal results to be the best performing system in winter. Compared to the concrete model, generally all categories improve the thermohygrometric performance of the sample building. In particular, the benefits on the outside face temperatures of the walls, which remain below the temperature of the outside air on hot summer days, are significant.

The results obtained refer to the simulated sample and therefore may vary in relation to the characteristics of the building analyzed (stratigraphy, number and size of windows, location, etc.) The simulation of a single sample and the non-determination of the contribu- 
tion of each term of the energy balance in energy efficiency can be considered limitations of the present research that can be developed in further research with a parametric study.

Author Contributions: Conceptualization, A.A., C.P. and M.C.; methodology, A.A., C.P. and M.C.; software, A.A., C.P. and M.C.; validation, A.A., C.P. and M.C.; formal analysis, A.A. and C.P.; investigation, A.A. and C.P.; data curation, A.A. and C.P.; writing-original draft preparation, C.P.; writing-review and editing, A.A.; visualization, A.A. and C.P.; supervision, A.A. and M.C.; project administration, A.A. All authors have read and agreed to the published version of the manuscript.

Funding: This research received no external funding.

Institutional Review Board Statement: Not applicable.

Informed Consent Statement: Not applicable.

Data Availability Statement: The data presented in this study are available in Perra, C.; Arenghi, A.; Caffi, M. Verde Verticale: Analisi Termoigrometriche in Regime Dinamico. DICATAM Technical Report 2020, 7, 1-199, [67].

Conflicts of Interest: The authors declare no conflict of interest.

\section{References}

1. Alexandri, E. Tackling the Heat Island Effect with Green Roofs and Green Walls: A Microclimatic Approach. In Proceedings of the WSA, 2nd Research Student Conference, Cardiff, Wales, May 2005.

2. Alexandri, E.; Jones, P. Temperature decreases in an urban canyon due to green walls and green roofs in diverse climates. Build. Environ. 2008, 43, 480-493. [CrossRef]

3. Djedjig, R.; Bozonnet, E.; Belarbi, R. Modeling green wall interactions with street canyons for building energy simulation in urban context. Urban Climate 2016, 16, 75-85. [CrossRef]

4. Li, J.; Zheng, B.; Shen, W.; Xiang, Y.; Chen, X.; Qi, Z. Cooling and Energy-Saving Performance of Different Green Wall Design: A Simulation Study of a Block. Energies 2019, 12, 2912. [CrossRef]

5. Rosenlund, H.; Kruuse, A.; Kronvall, J. Urban greenery in Sweden-Implications for microclimate and energy efficiency. In Proceedings of the World Green Roof Congress, London, UK, 3 September 2010. [CrossRef]

6. Farid, F.; Ahmad, S.; Raub, A.; Shaari, M. Green “Breathing Facades" for Occupants' Improved Quality of Life. Procedia Soc. Behav. Sci. 2016, 234, 173-184. [CrossRef]

7. Stav, Y. Transfunctional Living Walls-Designing Living Walls for Environmental and Social Benefits. Ph.D. Thesis, Queensland University of Technology, Brisbane City, Australia, 2016.

8. Malys, L.; Musy, M.; Inard, C. A hydrothermal model to assess the impact of green walls on urban microclimate and building energy consumption. Build. Environ. 2014, 73, 187-197. [CrossRef]

9. Dahanayake, K.C.; Chow, C.L. Comparing reduction of building cooling load through green roofs and green walls by EnergyPlus simulations. Build. Simul. 2018, 11, 421-434. [CrossRef]

10. Musy, M.; Malys, L.; Inard, C. Assessment of Direct and Indirect Impacts of Vegetation on Building Comfort: A Comparative Study of Lawns, Green Walls and Green Roofs. Procedia Environ. Sci. 2017, 38, 603-610. [CrossRef]

11. Boeri, S. Un Bosco Verticale — Libretto di Istruzioni per il Prototipo di una Città Foresta; Corraini Edizioni: Mantova, Italy, 2015.

12. Blanc, P. Vertical Gardens, the new Challenges. In Green Cities in the World, 2nd ed.; Briz, J., Köhler, M., de Felipe, I., Eds.; Editorial Agricola Espanola: Madrid, Spain, 2015; pp. 330-355.

13. Aksamija, A. High-Performance Building Envelopes: Design Methods for Energy-Efficient Facades. In Proceedings of the BEST4 Conference, Kansas City, MO, USA, 13-15 April 2015.

14. Safikhani, T.; Abdullah, A.; Ossen, D.; Baharvand, M. A review of energy characteristic of vertical greenery systems. Renew. Sust. Energ. Rev. 2014, 40, 450-462. [CrossRef]

15. Manso, M.; Castro-Gomes, J. Green wall systems: A review of their characteristics. Renew. Sust. Energ. Rev. 2015, 41, 863-871. [CrossRef]

16. Jim, C.Y. Greenwall classification and critical design-management assessments. Ecol. Eng. 2015, 77, 348-362. [CrossRef]

17. Pérez, G.; Coma, J.; Martorell, I.; Cabeza, L.F. Vertical Greenery Systems (VGS) for energy saving in buildings: A review. Renew. Sust. Energ. Rev. 2014, 39, 139-165. [CrossRef]

18. Jaafar, B.; Said, I.; Rasidi, M. Evaluating the Impact of Vertical Greenery System on Cooling Effect on High Rise Buildings and Surroundings: A Review. Rev. Urban. Archit. Stud. 2011, 9, 1-9. [CrossRef]

19. Wong, N.H.; Tan, A.; Chen, Y.; Sekar, K.; Tan, P.; Chan, D.; Chiang, K.; Wong, N. Thermal evaluation of vertical greenery systems for building walls. Build. Environ. 2010, 45, 663-672. [CrossRef]

20. Bit, E. Il Nuovo Verde Verticale: Tecnologie, Progetti, Linee Guida; Wolters Kluwer Italia S.r.l.: Assago (Milan), Italy, 2012.

21. Balogun, A.; Morakinyo, T.; Adegun, O. Effect of tree-shading on energy demand of two similar buildings. Energy Build. 2014, 81, 305-315. [CrossRef] 
22. Giometto, M.; Christen, A.; Egli, P.; Schmid, M.F.; Tooke, R.T.; Coops, N.C.; Parlange, M. Effects of trees on mean wind, turbulence and momentum exchange within and above a real urban environment. Adv. Water Resour. 2017, 106, 154-168. [CrossRef]

23. Hes, D.; Dawkins, A.; Jensen, C.; Aye, L. A modelling method to assess the effect of tree shading for building performance simulation. In Proceedings of the Building Simulation 2011, 12th Conference of International Building Performance Simulation Association, Sydney, New South Wales, Australia, 14-16 November 2011.

24. Lin, B.-S.; Lin, Y.-J. Cooling effect of shade trees with different characteristics in a subtropical urban park. HortScience 2010, 45, 83-86. [CrossRef]

25. Pandit, R.; Laband, D. A hedonic analysis of the impact of tree shade on summertime residential energy consumption. Arboric. Urban For. 2010, 36, 73-80.

26. Simpson, J.R.; McPherson, E.G. Simulation of tree shade impacts on residential energy use for space conditioning in Sacramento. Atmos. Environ. 1998, 32, 69-74. [CrossRef]

27. Akbari, H.; Kurn, D.; Bretz, S.; Hanford, J. Peak power and cooling energy savings of shade trees. Energy Build. 1997, 25, 139-148. [CrossRef]

28. Yoshimi, J.; Altan, H. Thermal simulations on the effects of vegetated walls on indoor building environments. In Proceedings of the Building Simulation 2011, 12th Conference of International Building Performance Simulation Association, Sydney, New South Wales, Australia, 14-16 November 2011.

29. Coma, J.; Perez, G.; Solé, C.; Castell, A.; Cabeza, L.F. New Green Facades as Passive Systems for Energy Savings on Buildings. Energy Procedia 2014, 57, 1851-1859. [CrossRef]

30. Kontoleon, K.; Eumorfopoulou, E. The effect of the orientation and proportion of a plant-covered wall layer on the thermal performance of a building zone. Build. Environ. 2010, 45, 1287-1303. [CrossRef]

31. Flores Larsen, S.; Filippín, C.; Lesino, G. Thermal Simulation of a Double Skin Façade with Plants. Energy Procedia 2014, 57, 1763-1772. [CrossRef]

32. Stec, W.; Paassen, A.; Maziarz, A. Modelling the double skin façade with plants. Energy Build. 2005, 37, 419-427. [CrossRef]

33. Chen, Q.; Li, B.; Xioahu, L. An experimental evaluation of the living wall system in hot and humid climate. Energy Build. 2013, 61, 298-307. [CrossRef]

34. Dahanayake, K.; Chow, C. Studying the Potential of Energy Saving through Vertical Greenery Systems: Using EnergyPlus Simulation Program. Energy Build. 2016, 138. [CrossRef]

35. Djedjig, R.; El Ganaoui, M.; Belarbi, R.; Bennacer, R. Thermal effects of an innovative green wall on building energy performance. Mech. Ind. 2017, 18. [CrossRef]

36. Scarpa, M.; Mazzali, U.; Peron, F. Modeling the energy performance of living walls: Validation against field measurements in temperate climate. Energy Build. 2014, 79, 155-163. [CrossRef]

37. Stanghellini, C.; van Meurs, W.T.M. Environmental control of greenhouse crop transpiration. J. Agric. Eng. Res. 1992, 51, $297-311$. [CrossRef]

38. Allen, R.; Pereira, L.; Smith, M. Crop Evapotranspiration-Guidelines for Computing Crop Water Requirements; FAO: Rome, Italy, 1998.

39. DOE. EnergyPlus Energy Simulation Software. 2015. Available online: https://energyplus.net/ (accessed on 31 March 2021).

40. Sailor, D.J. A green roof model for building energy simulation programs. Energy Build. 2008, 40, 1466-1478. [CrossRef]

41. Frankenstein, S.; Koenig, G. Fast All-Season Soil Strength (FASST); Cold Regions Research and Engineering Laboratory: Hanover, NH, USA, 2004.

42. Anderson, R.; Zhang, X.; Skaggs, T. Measurement and Partitioning of Evapotranspiration for Application to Vadose Zone Studies. Vadose Zone J. 2017, 16, 1-9. [CrossRef]

43. Del Barrio, E.P. Analysis of the green roofs cooling potential in buildings. Energy Build. 1998, 27, 179-193. [CrossRef]

44. Gutschick, V.P. Leaf Energy Balance: Basics, and Modeling from Leaves to Canopies. In Canopy Photosynthesis: From Basics to Applications; Hikosaka, K., Niinemets, Ü., Anten, N., Eds.; Springer: Dordrecht, The Netherlands, 2016; pp. 23-58.

45. Jayalakshmy, M.S.; Philip, J. Thermophysical Properties of Plant Leaves and Their Influence on the Environment Temperature. Int. J. Thermophys. 2010, 31, 2295-2304. [CrossRef]

46. Merzlyak, M.N.; Chivkunova, O.B.; Melø, T.B.; Naqvi, K.R. Does a leaf absorb radiation in the near infrared (780-900 nm) region? A new approach to quantifying optical reflection, absorption and transmission of leaves. Photosynth. Res. 2002, 72, 263-270. [CrossRef] [PubMed]

47. Oke, T.R. Boundary Layer Climates, 2nd ed.; Routledge Taylor \& Francis Group: London, UK, 1987; pp. 1-157.

48. Šuklje, T.; Medved, S.; Arkar, C. On detailed thermal response modeling of vertical greenery systems as cooling measure for buildings and cities in summer conditions. Energy 2016, 115 Pt 1, 1055-1068. [CrossRef]

49. Davis, M.M.; Hirmer, S. The Potential for Vertical Gardens as Evaporative Coolers: An Adaptation of the 'Penman Monteith Equation'. Build. Environ. 2015, 92. [CrossRef]

50. Monteith, J.L.; Unsworth, M.H. Principles of Environmental Physics: Plants, Animals, and the Atmosphere, 4th ed.; Elsevier: Oxford, UK, 2013.

51. Monteith, J.L. Principles of Environmental Physics; Edward Arnold Limited: London, UK, 1973.

52. Defraeye, T.; Blocken, B.; Carmeliet, J. Convective heat transfer coefficients for exterior building surfaces: Existing correlations and CFD modelling. Energy Convers. Manag. 2011, 52, 512-522. [CrossRef] 
53. Asner, G.P.; Scurlock, J.M.O.; Hicke, J.A. Global synthesis of leaf area index observations: Implications for ecological and remote sensing studies. Glob. Ecol. Biogeogr. 2003, 12, 195-205. [CrossRef]

54. Goswami, S.; Gamon, J.; Vargas Zesati, S.; Tweedie, C. Relationships of NDVI, Biomass, and Leaf Area Index (LAI) for six key plant species in Barrow, Alaska. PeerJ Prepr. 2015. [CrossRef]

55. Candelari, E. Caratterizzazione Sperimentale della Prestazione Termica e Acustica di un Living Wall. Ph.D. Thesis, Politecnico di Torino, Torino, Italy, 2015.

56. Gu, L. Airflow network modeling in energyplus. In Proceedings of the 10th International Building Performance Simulation Association, Conference and Exhibition, Beijing, China, 3-6 September 2007.

57. Peci-López, F.; Jensen, R.; Heiselberg, P.; Ruiz de Adana, M. Experimental analysis and model validation of an opaque ventilated facade. Build. Environ. 2012, 56, 265-275. [CrossRef]

58. Le, S.; Chen, Y.; Bi, Y.; Lu, X. Modeling and Simulation of Ventilated Double-Skin Facade Using EnergyPlus. In Proceedings of the 8th International Symposium on Heating, Ventilation and Air Conditioning, Sydney, New South Wales, Australia, 16-17 July 2014; Lecture Notes in Electrical Engineering. Li, A., Zhu, Y., Li, Y., Eds.; Springer: Berlin/Heidelberg, Germany, 2014; Volume 263, pp. 241-252. [CrossRef]

59. Abu-Hamdeh, N.H.; Reeder, R.C. Soil thermal conductivity: Effects of density, moisture, salt concentration and organic matter. Soil Sci. Soc. Am. J. 2000, 64, 1285-1290. [CrossRef]

60. Akpabio, G.T.; Ituen, E.E.; Ikot, A.N. A Comparative Study of the Thermal Properties of Different Soil Samples for Moulding Blocks for a Passively Cooled Building Design. Int. J. Pure Appl. Phys. 2010, 6, 517-521.

61. Clauser, C.; Huenges, E. Thermal conductivity of rocks and minerals. In Rock Physics E Phase Relations: A Handbook of Physical Constants; Ahrens, T.J., Ed.; American Geophysical Union: Washington, DC, USA, 1995; pp. 105-126.

62. Fuchs, M. Energy Balance. In Encyclopedia of Soils in the Environment, 1st ed.; Hillel, D., Ed.; Elsevier: Amsterdam, The Netherlands, 2005; pp. 438-441.

63. Han, S.; Chun, S.; Kim, K.; Lawrence, A.; Tia, M.; Said, Z. Evaluation of Soil Insulation Effect on Thermal Behavior of Drilled Shafts as Mass Concrete. Cogent Eng. 2018, 5. [CrossRef]

64. Nikoosokhan, S.; Nowamooz, H.; Chazallon, C. Effect of dry density, soil texture and time-spatial variable water content on the soil thermal conductivity. Geomech. Geoeng. 2015, 11, 1-10. [CrossRef]

65. Pitts, L. Monitoring Soil Moisture for Optimal Crop Growth. 2016. Available online: https:/ / observant.zendesk.com/hc/en-us/ articles/208067926-Monitoring-Soil-Moisture-for-Optimal-Crop-Growth (accessed on 31 March 2021).

66. EnergyPlus. Weather Data by Region. Available online: https://energyplus.net/weather-region/europe_wmo_region_6/ITA\% 20\%20 (accessed on 31 March 2021).

67. Perra, C.; Arenghi, A.; Caffi, M. Verde Verticale: Analisi Termoigrometriche in Regime Dinamico. DICATAM Tech. Rep. 2020, 7 , 1-199.

68. Perez, G.; Rincon, L.; Vila, A.; Gonzalez, J.M.; Cabeza, L.F. Green vertical systems for buildings as passive systems for energy savings. Appl. Energy 2011, 88, 4854-4859. [CrossRef]

69. Mazzali, U.; Fabio, P.; Romagnon, P.; Pulselli, R.M.; Bastianoni, S. Experimental investigation on the energy performance of Living Walls in a temperate climate. Build. Environ. 2013, 64, 57-66. [CrossRef]

70. Cameron, R.W.F.; Taylor, J.; Emmett, M. A Hedera green façade -energy performance and saving under different maritimetemperate, winter weather conditions. Build. Environ. 2015, 92, 111-121. [CrossRef]

71. Haggag, M.; Hassan, A.; Elmasry, S. Experimental study on reduced heat gain through green façades in a high heat load climate. Energy Build. 2014, 82, 668-674. [CrossRef]

72. Hoelscher, M.-T.; Nehls, T.; Jänicke, B.; Wessolek, G. Quantifying cooling effects of facade greening: Shading, transpiration and insulation. Energy Build. 2015, 114, 283-290. [CrossRef]

73. Perini, K.; Ottelé, M.; Fraaij, A.L.A.; Haas, E.; Raiteri, R. Vertical greening systems and the effect on air flow and temperature on the building envelope. Build. Environ. 2011, 46, 2287-2294. [CrossRef] 